\title{
Oleophilicity and Oil-Water Separation by Reduced Graphene Oxide Grafted Oil Palm Empty Fruit Bunch Fibres
}

(Oleofilisiti dan Pemisahan Minyak-Air oleh Grafin Oksida Terturun Tercantum Gentian Tandan Kosong Kelapa Sawit)

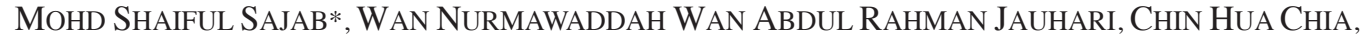 \\ SARANI ZAKARIA HATIKA KACO \& AN'AMT MOHAMED NOOR
}

\begin{abstract}
Absorption is one of the effective, simple and economical methods to remove oil from oily wastewater. The most widely used approach is to utilize lignocellulosic biomass as oil absorbent. However, the hygroscopic of cellulose have limited the oil-water separation capability of lignocellulosic fibers. In this study, the surface functionality of oil palm empty fruit bunch (EFB) fibers was slightly altered by grafting reduced graphene oxide ( $\mathrm{GO} O)$. The modified EFB fibers show a distinct morphological and chemical characteristics changes as the surface of fibers has been coated with $r G O$. This was supported by FTIR analysis with the diminishing peak of hydroxyl group region of EFB fibers. While the surface modification on EFB fibers shows a diminution of a hydrophilic characteristic of $131.6 \%$ water absorption in comparison with 268.9\% of untreated EFB fibers. Moreover, modified fibers demonstrated an oil-water separation increment as well, as it shows $89 \%$ of oil uptake and improved 17 times of oil selectivity in oil-water emulsion than untreated EFB fibers.
\end{abstract}

Keywords: Absorption; hydrophobic; lignocellulose; oil recovery; reduced graphene oxide

\section{ABSTRAK}

Penyerapan merupakan salah satu kaedah yang berkesan, mudah dan berekonomi untuk menyingkirkan minyak daripada air buangan berminyak. Antara pendekatan paling banyak digunakan secara meluas adalah dengan menggunakan biojisim lignoselulosa sebagai penyerap minyak. Walau bagaimanapun, higroskopi selulosa telah membataskan keupayaan pemisahan minyak-air bagi gentian lignoselulosa. Dalam kajian ini, permukaan berfungsi gentian tandan kosong kelapa sawit (EFB) telah diubah sedikit dengan mencantumkan grafin oksida terturun (rGO). Gentian EFB terubah suai menunjukkan perubahan morfologikal dan ciri kimia yang berbeza dengan permukaan gentian yang telah disaluti oleh rGO. Ia telah disokong dengan analisis FTIR dengan pengurangan puncak kawasan kumpulan hidroksil gentian EFB. Sementara itu, pengubahsuaian permukaan gentian EFB telah menunjukkan pengurangan ciri hidrofilik, menghasilkan $131.6 \%$ penyerapan air berbanding dengan $268.9 \%$ bagi gentian EFB tanpa rawatan. Malah, gentian terawat juga menunjukkan peningkatan terhadap pemisahan minyak-air dengan melihatkan $89 \%$ pengambilan minyak, dan menambah baik 17 kali ganda daripada gentian EFB tanpa rawatan.

Kata kunci: Grafin oksida terturun; hidrofobik; lignoselulosa; penjerapan; perolehan minyak

\section{INTRODUCTION}

Absorption has long been known as one of the most effective and economical methods for the removal of oil in wastewater (Adebajo et al. 2003; Wahi et al. 2013). Although the wide selection of this method can be generated by the natural abundance of carbon, polymers, clays and lignocellulosic fibers. However, high separation selectivity of oil in oil-water emulsion and biodegradability should factorize the ideal of oil absorbent (Deschamps et al. 2003; Hussein et al. 2008; Liu et al. 2013). In the previous study, lignocellulosic adsorbent has provided a potential replacement of activated carbon for the removal of dyes, organic matter and metal ions. However, the hydroxyl groups comprise in the cellulosic composition contributed a high hydrophilicity, which affected the effectiveness to remove oil ( $\mathrm{Li}$ et al. 2013). Thus, an appropriate surface treatment and chemical modification of cellulosic absorbent have reported increase the hydrophobicity property of the fibers (Deschamps et al. 2003; Feng et al. 2015; Wang et al. 2015).

Practically, to form hydrophobic-oleophilic materials, the surface of the absorbent can be modified through physical and chemical modification by improving the rough structure on the surface material and increasing the low surface energy on the surface of the materials (Wang et al. 2015). In most of the cases, acetylation and organosilanes grafting were a perfect match for surface modification due to the compatibility of acetylated cellulose-oil ( $\mathrm{Li}$ et al. 2013). Whereas, grafted silanes on the surface of the materials via chemical vapor deposition will modify the interaction of boundary layers between solids and water (Arkles 2016; Feng et al. 2015). Recently, interesting 
approach by introducing graphene oxide (GO) as chemical grafting also provide a very promising result, which has been widely used for water remediation (Chia et al. 2013; Liu et al. 2013; Qin et al. 2015).

In our previous study, oil palm empty fruit bunch (EFB) fibers have been used as adsorbent material to remove chemical substances for water remediation (dyes, metal ions and organic compounds of paper mill effluent) (Sajab et al. 2014, 2013). In this work, in order to provide a better selectivity toward oil separation, EFB fibers was pretreated and surface modified with subsequence method of alkalineoxidative pretreatment and surface grafting with reduced graphene oxide (rGO). The oil-water separation selectivity performance of untreated and modified EFB fibers was investigated by series of oil and water absorption.

\section{MATERIALS}

Oil palm empty fruit bunch (EFB) fibers were obtained from the Malaysian Agricultural Research and Development Institute (MARDI). Used engine oil was collected at the local automobile workshop nearby Bangi, Selangor. Graphene oxide (GO) was prepared by using graphite flakes (Ashbury, Inc. USA), phosphoric acid, 85\% (Merck), potassium permanganate, $99.9 \%$ (Merck) and hydrogen peroxide, $30 \%$ (Merck).

\section{METHODS}

\section{ALKALINE-OXIDATIVE PRETREATMENT}

The alkaline pretreatment of EFB fibers (EFB/AO) started with an alkaline wash of $50 \mathrm{~g} / \mathrm{L}$ fibers to $0.1 \mathrm{M} \mathrm{NaOH}$ ratio and stirred at $500 \mathrm{rpm}$ for $1 \mathrm{~h}$ by magnetic stirrer as followed by our previous study (Sajab et al.2013). After the alkaline treatment, 2 wt. \% of $\mathrm{H}_{2} \mathrm{O}_{2}$ was added and stirred for $24 \mathrm{~h}$ until all oxidation reaction has been performed (Santanaraj et al. 2017). Then, the treated fibers were washed with deionized water to remove the excesses of $\mathrm{H}_{2} \mathrm{O}_{2}$ and $\mathrm{NaOH}$. The treated EFB fibers dried overnight at $105^{\circ} \mathrm{C}$.

\section{EFB FIBERS GRAFTED GRAPHENE OXIDE}

GO was first synthesized by using simplified Hummer's method. The method was selected according to our previous work (Chia et al. 2013). Briefly, graphite flakes (3 g) was added into a 9:1 $\mathrm{H}_{2} \mathrm{SO}_{4}: \mathrm{H}_{3} \mathrm{PO}_{4}(360: 40 \mathrm{~mL})$ solution and gradually added of $\mathrm{KMnO}_{4}(18 \mathrm{~g})$. The oxidation process was stopped by ice $(\sim 400 \mathrm{~mL})$ along with $30 \mathrm{wt}$. $\% \mathrm{H}_{2} \mathrm{O}_{2}(27 \mathrm{~mL})$. The solution was centrifuged at 12,000 rpm for $30 \mathrm{~min}$ and washed three times with $1 \mathrm{M} \mathrm{HCl}$ and ten times with deionized water. The diluted GO $(1 \mathrm{mg} /$ $\mathrm{mL}$ ) was mixed with the EFB fibers with the ratio of 50 $\mathrm{g} / \mathrm{L}$. The mixture of GO and EFB fibers was stirred for $1 \mathrm{~h}$ at room temperature. The sample was placed in an oven at a temperature of $180^{\circ}$ for $3 \mathrm{~h}$ to reduce the GO to $\mathrm{rGO}$ (EFB-rGO). These steps were repeated with EFB/AO fibers to form onto EFB/AO-rGO fibers.

\section{OIL-WATER SELECTIVITY}

In a water selectivity study, the absorption of water in EFB fibers was performed at a ratio of $4-12 \mathrm{~g} / \mathrm{L}$ at a 200 rpm and left for $24 \mathrm{~h}$. The sample was filtered using 0.45 $\mu \mathrm{m}$ membrane filter and measured the water absorption by moisture analyzer (Denver Instrument). In oil-water separation, oil selectivity was measured by the amount of oil to water ratio absorbed in the EFB fibers. In general, 2-10 wt. $\%$ of used engine oil was homogenized with water for 10 min and a mixture of EFB fibers with oil-water emulsion was continuously stirred for $1 \mathrm{~h}$. The initial weight of absorbent by oil-water mixture was recorded. Later, the absorbent was dried at $105^{\circ} \mathrm{C}$ for $24 \mathrm{~h}$ to remove water absorbed in the absorbent. The initial and final weight of the absorbent was measured to calculate the absorbed amount of used engine oil at final equilibrium $\left(q_{\mathrm{e}}\right)$ using the following equation (Sajab et al. 2014),

$$
q_{\mathrm{e}}=\frac{\left(C_{0-} C_{\mathrm{e}}\right) V}{m}
$$

where $C_{0}$ and $C_{\mathrm{e}}$ are the initial and equilibrium concentrations of the oil-water emulsion ( $\mathrm{mg} / \mathrm{L})$, respectively, $V$ is the total volume of the oil-water emulsion $(\mathrm{mL})$ and $m$ is the mass of the absorbent $(\mathrm{g})$. These experiments were replicated three times and followed by treated EFB fibers, EFB-rGO and EFB/AO-rGO.

\section{CHARACTERIZATIONS}

Synthesized GO was analyzed using a transmission electron microscopy (TEM) (CM 12 Phillips). The sample was diluted using ethanol (ca. $0.01 \mathrm{wt} . \%$ ) and dropped onto a copper grid and stained with uranyl acetate (3 wt. \%). The morphological changes were observed by field emission scanning electron microscope, FESEM (Merlin Compact, Zeiss Pvt. Ltd.) Attenuated total reflectance Fourier transform infrared spectroscopy (ATR-FTIR) (ALPHA FTIR Spectrometer, Bruker) characterization for the functional groups of the samples was performed in the resolution of $1 \mathrm{~cm}^{-1}$ in the range of 4000 to $650 \mathrm{~cm}^{-1}$.

\section{RESULTS AND DISCUSSION}

\section{CHARACTERIZATIONS OF MODIFIED EFB FIBERS}

Figure 1(a) shows the TEM image of GO and independent GO sheets were observed. This single layer of GO sheets was larger than $0.5 \mu \mathrm{m}$ in wideness because of the existence of a large amount of oxygen-containing functional groups on both sides of the plane and around the edges as described by Lerf-Klinowski model (1998). In addition, the exfoliation of GO up to single layer was due to the diminishing van der Waals interactions between Go layers through the sonication process (Changjing et al. 2013). The morphological structure of EFB fibers observed by FESEM shows a high amount of silica bodies with the rough surface structure on the surface of the untreated fibers (Figure 1(b)). 

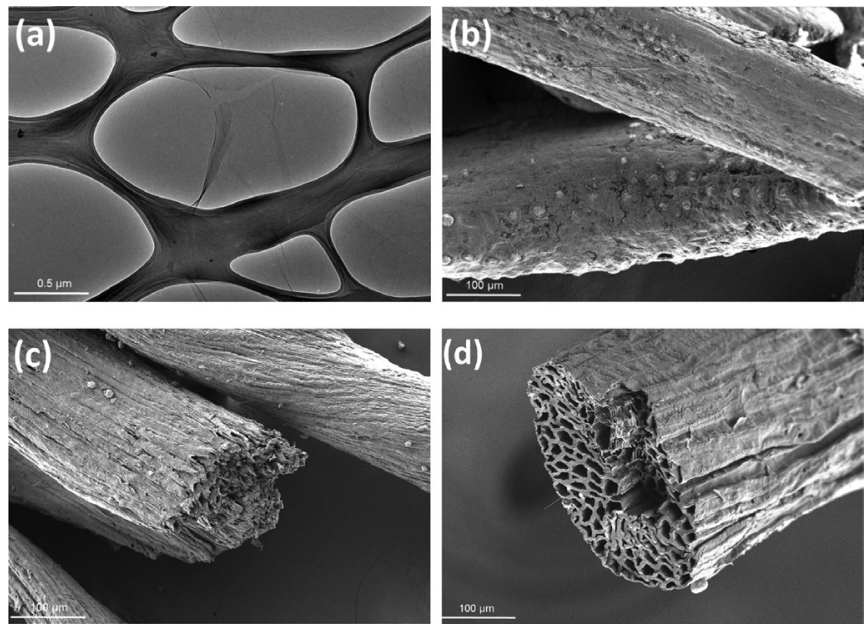

FIGURE 1. TEM micrograph image of (a) GO suspension and morphological images of FESEM on (b) untreated EFB (c) EFB-rGO and (d) EFB/AO-rGO

In the addition of rGO coated on the surface of the fibers (Figure 1(c) and 1(d)), multiple rGO sheets can be observed overlay on the surface of the fibers. Whereas, the pretreated fibers by alkaline-oxidization (Figure 1(d)) before coated with GO shows more porous structure by the visible lumen of the fibers. The porosity of treated fibers shows the successful removal of wax, lignin and silica through delignification process (Santanaraj et al. 2017).

The comparison of FTIR spectrum between GO, untreated and modified EFB fibers were carried out in order to identify the distinct changes in a functional group of cellulosic fibers and reduce GO as shown in Figure 2. In the FTIR spectrum of GO, a broad peak can be seen between $3100-3600 \mathrm{~cm}^{-1}$ and a sharp peak at $1632 \mathrm{~cm}^{-1}$ corresponding to the stretching and bending vibration of $\mathrm{OH}$ groups of water molecules on synthesized GO. Moreover, a general characteristic of functional groups in lignocellulosic fibers can be recognized between 3100$3600 \mathrm{~cm}^{-1}, 1620-1720 \mathrm{~cm}^{-1}$ of hydroxyl, carbonyl and carbonyl groups, respectively (Sajab et al. 2013). While

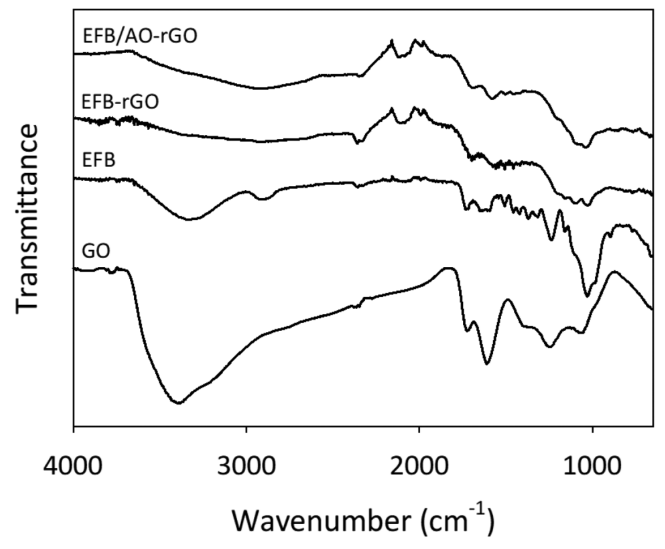

FIGURE 2. FTIR spectrum of GO, untreated EFB fibers and modified EFB fibers with pretreated alkaline oxidative and functionalized $\mathrm{rGO}$ a broad absorption peak of hydroxyl groups of EFB fibers is diminishing after the surface modification by reduced graphene oxide for EFB-rGO and EFB/AO-rGO. Thermally reduced graphene oxide has been deoxygenated and overlay the hydroxyl groups on the surface of modified fibers (Qin et al. 2015). Considering the hygroscopic of the EFB fibers is mainly bound by the hydroxyl groups in the lignocellulosic fibers, the reduction of the $\mathrm{O}-\mathrm{H}$ bond of hydroxyl group will promote the hydrophobicity of the treated fibers (Li et al. 2013).

\section{WATER UPTAKE OF CHEMICALLY MODIFIED EFB FIBERS}

The water uptake of EFB fibers was shown in Figure 3. The untreated EFB fibers demonstrate the highest water uptake with $268.9 \%$ of water absorption. The strong hydrophilicity of the untreated EFB fibers is due to the hydroxyl groups which largely occur in cellulose composition for the lignocellulosic material ( $\mathrm{Li}$ et al. 2013; Nguyen et al. 2003). Meanwhile, the modified EFB fibers have been reduced its hydrophilicity with the

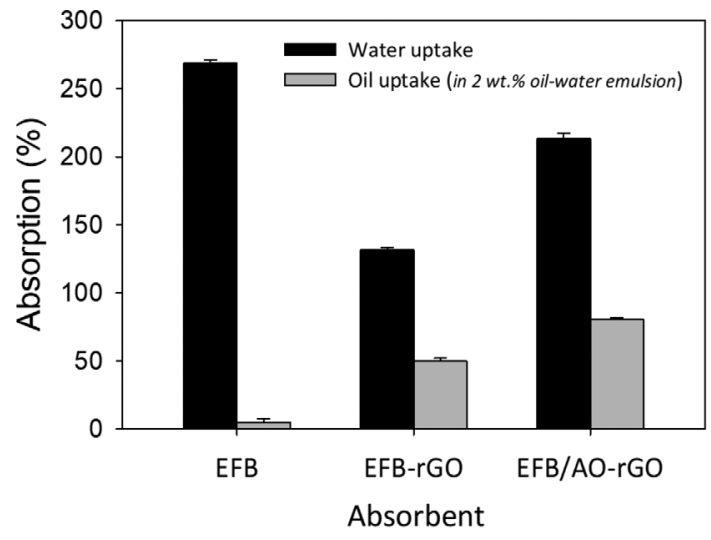

FIGURE 3. Water absorption and oil-water separation of untreated EFB fibers and modified EFB fibers of pretreated alkaline oxidative with functionalized $\mathrm{rGO}$ 
reduction of water absorption of 51.0 and $20.7 \%$ for EFB-rGO and EFB/AO-rGO, respectively. EFB/AO-rGO shows an increment of water uptake in comparison with EFB-rGO even though the modified fibers have been coated with the rGO. This might be a result of alkalineoxidation treatment towards the fiber lumen exposure and allowed physical absorption between the fibers and water (Santanaraj et al. 2017). Subsequently, the diminution of the water uptake by chemically modified EFB fibers has been resulted in the increasing of the oil uptake up to $75.7 \%$ in comparison with $44.9 \%$ of untreated fibers.

\section{OIL-WATER EMULSION SEPARATION OF CHEMICALLY MODIFIED EFB FIBERS}

The oil separation by EFB/AO-rGO fibers shows in Figure 4 shows the tendency of oil to coagulate on the surface of the fibers. This slightly exhibits an improvement of the surface oleophilicity modification by rGO. However, the mechanism of the separation selectivity should investigate through the oil-water emulsion separation rather than solely depending on the maximum oil uptake of oil absorption. Thus, in the oil-water separation study, the oil uptake has been carried out at different amount of EFB/AO-rGO dosage (0.2-0.6 g) in the series of oil-water emulsion (2-10 wt. $\%)$. As a result, the increment of absorbent dosage has enhanced the oil uptake of the EFB/AO-rGO up to $89.4 \%$ of
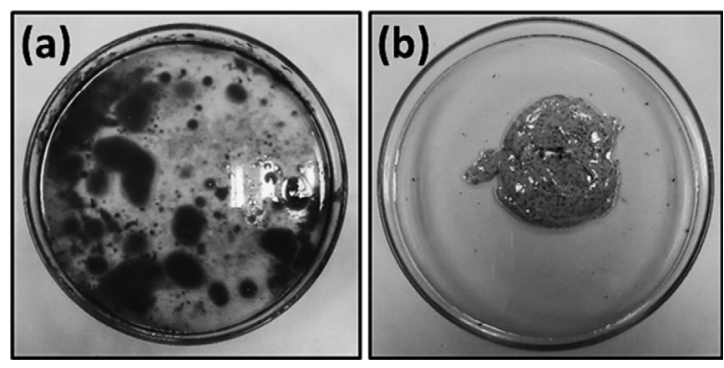

FIGURE 4. Comparison of oil separation by using (a) untreated EFB fibers and (b) functionalized EFB fibers with rGO

(a)

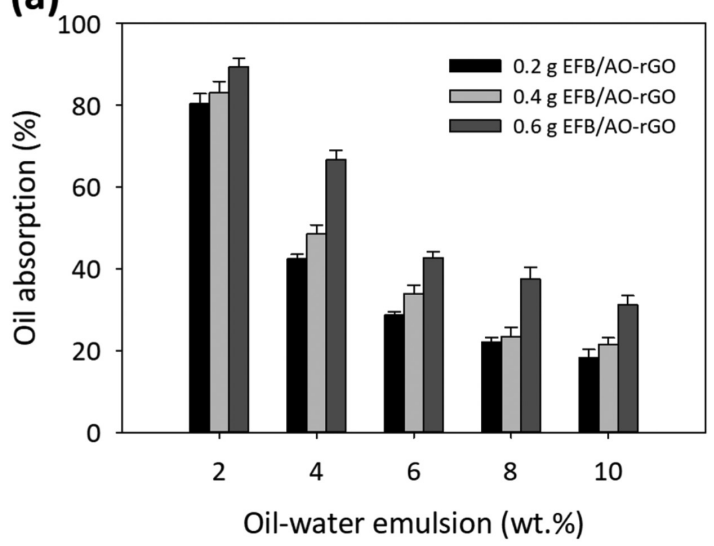

oil absorption at $0.6 \mathrm{~g}$ (Figure 5). Theoretically, additional of the absorbent dosage provided more surface area of the absorbent to uptake and retain oil absorbed (Yang et al. 2014). Nonetheless, the increasing of oil concentration (2 to 10 wt. \%) in oil-water emulsion shows an immense decline in oil separation efficiency with a reduction to $18.3,21.5$ and $31.2 \%$ at $0.2,0.4$ and $0.6 \mathrm{~g}$ of $\mathrm{EFB} / \mathrm{AO}-\mathrm{rGO}$, respectively.

The optimum uptake of the oil recovery can be calculated by fitting the adsorption models in the non-linear equation of the Langmuir and Freundlich isotherm models (2 and 3), which can be expressed as (Freundlich 1906; Langmuir 1917),

$$
q_{\mathrm{e}}=\frac{Q_{0} b C_{\mathrm{e}}}{1+b C_{\mathrm{e}}}
$$

where $Q_{0}$ is the maximum adsorption capacity per unit mass of absorbent $(\mathrm{mg} / \mathrm{g})$; and $b$ is a constant related to the adsorption energy $(\mathrm{L} / \mathrm{mg})$.

$$
q_{\mathrm{e}}=K_{\mathrm{F}} C_{\mathrm{e}}^{1 / n_{\mathrm{F}}}
$$

where $K_{\mathrm{F}}$ and $1 / n_{\mathrm{F}}$ are the Freundlich constants, with $K_{\mathrm{F}}$ representing the relative adsorption capacity $((\mathrm{mg} / \mathrm{g})(\mathrm{L} /$ $\left.\mathrm{mg})^{1 / n}\right)$ ) of the absorbent and $n_{\mathrm{F}}$ representing the degree of dependence of adsorption on the equilibrium concentration of oil-water emulsion. In general, the assumption mechanism of the Langmuir model represented the monolayer interaction between the oil molecules and the surface of the EFB fibers. While Langmuir explains on the homogeneous interaction, the Freundlich model considers the heterogeneous interaction behavior of the adsorbentadsorbate mechanism. The higher correlation coefficients $\left(r^{2}\right)$ of the experimental data was well fitted with Freundlich (0.983-0.9989) in comparison with Langmuir (0.9790.997 ) indicates the heterogeneous interaction between oil and adsorbent due to the oil-water composition in the (b)

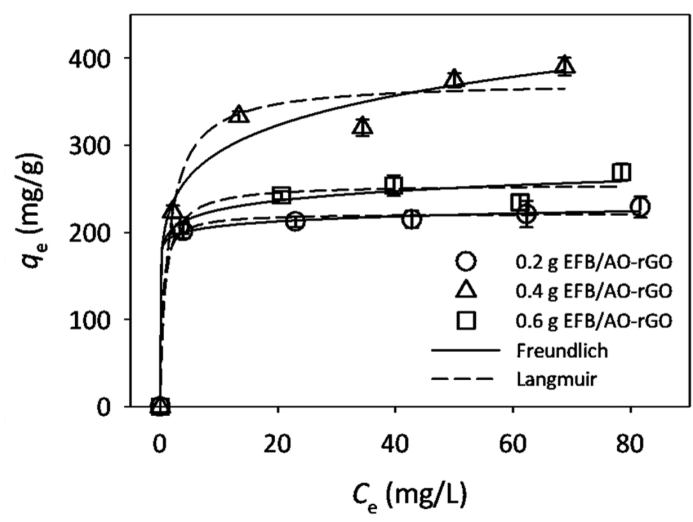

FIGURE 5. The efficiency of (a) oil selectivity in oil-water separation and (b) fitted Langmuir and Freundlich models by modified EFB fibers of pretreated alkaline oxidative with functionalized rGO (EFB/AO-rGO) 
emulsion and the oleophilicity of rGO. Moreover, the estimated maximum oil adsorption $\left(Q_{0}\right)$ of EFB/AO-rGO at different adsorbent dosages of 0.2, 0.4 and $0.6 \mathrm{~g}$ are calculated as $189.6,221.8$ and $372.9 \mathrm{mg} / \mathrm{g}$, respectively. The high separation selectivity of the chemically modified EFB fibers performed a competitive performance with activated carbon $(468 \mathrm{mg} / \mathrm{g})$ shows in a previous study (Okiel et al. 2011).

\section{CONCLUSION}

In this study, alkaline-oxidative pretreatment exhibit as an effective pretreatment of EFB fibers through the improvement of the surface area of the adsorbent. Whereas, the modification of the EFB fibers with rGO show strong oleophilicity and better oil selectivity in the oil-water emulsion. However, since the composition of lignocellulosic is naturally hydrophilic, the additional properties of hydrophobicity of rGO gave the complex mechanism of the oil uptake which is supported by the heterogeneous interaction between adsorbent-adsorbent assumption by Freundlich adsorption model.

\section{ACKNOWLEDGEMENTS}

This research was supported by research grants from UKM (GGPM-2016-025) and the Ministry of Higher Education, Malaysia (R/FRGS/A08.00/00648A/001/2016/000368).

\section{REFERENCES}

Adebajo, M., Frost, R., Kloprogge, J., Carmody, O. \& Kokot, S. 2003. Porous materials for oil spill cleanup: A review of synthesis and absorbing properties. J. of Porous Materials 10: $159-170$.

Arkles, B. 2016. Hydrophobicity, hydrophilicty and silanes. Paint \& Coating Industry 22(10): 114-132.

Changjing, F., Zhao, G., Zhang, H. \& Li, S. 2013. Evaluation and characterization of reduced graphene oxide nanosheets as anode materials for lithium-ion batteries. Inter. J. of Elect. Sci. 8: 6269-6280.

Chia, C.H., Razali, N.F., Sajab, M.S., Zakaria, S., Huang, N.M. \& Lim, H.N. 2013. Methylene blue adsorption of graphene oxide. Sains Malaysiana 42(6): 819-826.

Deschamps, G., Caruel, H., Borredon, M.E., Bonnin, C. \& Vignoles, C. 2003. Oil removal from water by selective sorption on hydrophobic cotton fibers. 1. Study of sorption properties and comparison with other cotton fiber-based sorbents. Environ. Sci. Technol. 37(5): 1013-1015.

Feng, J., Nguyen, S.T., Fan, Z. \& Duong, H.M. 2015. Advanced fabrication and oil absorption properties of super-hydrophobic recycled cellulose aerogels. Chem. Eng. J. 270: 168-175.

Freundlich, H.M.F. 1906. Over the adsorption in solution.J.Phys. Chem. 57A: 385-470.

Hussein, M., Amer, A.A. \& Sawsan, I.I. 2008. Oil spill sorption using carbonized pith bagasse. 1. Preparation and characterization of carbonized pith bagasse. J. Anal. Appl. Pyrolysis. 82(2): 202-211.

Langmuir, I. 1916. The constitution and fundamental properties of solid and liquids. Part 1: Solid.J.Am. Chem. Soc. 39(11): 2221-2295.
Lerf, A., He, H., Forster, M. \& Klinowski, J. 1998. Structure of graphite oxide revisited. J. Phy. Chem. 102: 4477-4482.

Li, D., Zhu, F.Z., Li, J.Y., Na, P. \& Wang, N. 2013. Preparation and characterization of cellulose fibers from corn straw as natural oil sorbents. Ind. Eng. Chem. Res. 52(1): 516-524.

Liu, Y., Ma, J.K., Wu, T., Wang, X.R., Huang, G.B., Liu, Y., Qiu, H.X., Li, Y., Wang, W. \& Gao, J.P. 2013. Cost-effective reduced graphene oxide-coated polyurethane sponge as a highly efficient and reusable oil-absorbent. ACS Appl.Mater. Interfaces 5(20): 10018-10026.

Nguyen, S., Feng, J., Le, N., Le, T., Hoang, N., Tan, V. \& Duong, M. 2013. Cellulose aerogel from paper waste for crude oil spill cleaning. Ind. and Eng. Chem. Res. 52(51): 18386-18391.

Okiel, K., El-sayed, M. \& El-kady, M.Y. 2011. Treatment of oil-water emulsions by adsorption onto activated carbon, bentonite and deposited carbon. Egyptian Journal of Petroleum 20(2): 9-15.

Qin, H., Gong, T., Cho, Y., Shin, C., Lee, C. \& Kim, T. 2015. A simple and economical method using graphene oxide for the fabrication of water/oil separation papers. RSC Adv. 5: 57860-57864.

Sajab, M.S., Chia, C.H., Zakaria, S. \& Sillanpää, M. 2014. Removal of organic pollutants and decolorization of bleaching effluents from pulp and paper mill by adsorption using chemically treated oil palm empty fruit bunch fibers. Bioresources 9(3): 4517-4527.

Sajab, M.S., Chia, C.H.,Zakaria, S. \& Khiew, P.S. 2013. Cationic and anionic modifications of oil palm empty fruit bunch fibers for the removal of dyes from aqueous solutions. Bioresource Technology 128(71): 571-577.

Santanaraj, J., Sajab, M.S., Mohammad, A.W., Harun, S., Chia, C.H.,Zakaria, S. \& Kaco, H. 2017. Enhanced delignification of oil palm empty fruit bunch fibers with in situ Fentonoxidation. Bioresources 12(3): 5223-5235.

Wahi, R., Chuah, A., Choong, T. \& Mobarekeh, M. 2013. Oil removal from aqueous state by natural fibrous sorbent. Journal of Separation and Purification Technology 113: 51-63.

Wang, B., Liang, W., Guo, Z.\& Liu, W. 2015. Biomimetic superlyophobic and super-lyophilic materials applied for oil/water separation: A new strategy beyond nature. Chem. Soc. Rev. 44(91): 336-361.

Wang, Z., Barford, J.P., Hui, C.W. \& McKay, G. 2015. Kinetic and equilibrium studies of hydrophilic and hydrophobic rice husk cellulosic fibers used as oil spill sorbents. Chemical Engineering Journal 281: 961-969.

Mohd Shaiful Sajab*

Chemical Engineering Programme

Faculty of Engineering and Built Environment

Universiti Kebangsaan Malaysia

43600 UKM Bangi, Selangor Darul Ehsan

Malaysia

Mohd Shaiful Sajab* \& Wan Nurmawaddah Wan Abdul Rahman Jauhari

Research Centre for Sustainable Process Technology (CESPRO)

Faculty of Engineering and Built Environment

Universiti Kebangsaan Malaysia

43600 UKM Bangi, Selangor Darul Ehsan

Malaysia 
Chin Hua Chia \& Sarani Zakaria

School of Applied Physics

Faculty of Science and Technology

Universiti Kebangsaan Malaysia

43600 UKM Bangi, Selangor Darul Ehsan

Malaysia

Hatika Kaco

Kolej Permata Insan

Universiti Sains Islam Malaysia

Bandar Baru Nilai

71800 Nilai, Negeri Sembilan Darul Khusus

Malaysia
An'amt Mohamed Noor

Fakulti Agro Industri dan Sumber Asli

Universiti Malaysia Kelantan

Karung Berkunci 36, Pengkalan Chepa

16100 Kota Bharu, Kelantan Darul Naim

Malaysia

*Corresponding author; email: mohdshaiful@ukm.edu.my

Received: 1 March 2018

Accepted: 5 April 2018 